\title{
EFFECTS OF BLEEDING ON THE CORROSION OF HORIZONTAL STEEL BARS IN REINFORCED CONCRETE COLUMN SPECIMENS
}

\author{
Nevy Sandra ${ }^{1,2^{*}}$, Keiyu Kawaai $^{1}$, Isao Ujike ${ }^{1}$, Ippei Nakai ${ }^{1}$, Willick Nsama ${ }^{1}$ \\ ${ }^{1}$ Graduate School of Science and Engineering, Ehime University, 3, Bunkyocho, Matsuyama, Ehime \\ 790-8577, Japan \\ ${ }^{2}$ Department of Civil Engineering, Faculty of Engineering, Universitas Negeri Padang, Jalan Hamka, \\ Air Tawar Padang, West Sumatera, Indonesia
}

(Received: October 2018 / Revised: November 2018 / Accepted: July 2019)

\begin{abstract}
The durability of reinforced concrete has proven to be predominantly influenced by its resistance against the ingress of harmful substances such as chloride ions, carbon dioxide and moisture. The corrosion of steel bars which occurs especially in marine environments is likely to be severe, depending on the availability of oxygen and the moisture consumed by cathodic reactions. This study aims to investigate the effects of bleeding on the corrosion of horizontal steel bars placed in reinforced concrete column specimens. The issue was examined through electro-chemical tests, including half-cell potential, polarization resistance and corrosion current density, conducted using specimens in which corrosion was induced via dry and wet $(\mathrm{NaCl} 10 \%)$ cycles. The presence or absence of copper slag fine aggregate and fly ash replacement was employed as an experimental parameter. The results suggest that the corrosion of horizontal steel bars in the upper part of the column concrete specimens was adversely affected, even in the case of OPC specimens with relatively lower bleeding water. This was attributed to lower resistance against the ingress of corrosive substances, especially in such locations. In the case of fly ash mixtures, resistance to corrosion was significantly improved owing to lower oxygen permeability of less than $1.0 \times 10^{-11} \mathrm{~mol} / \mathrm{cm}^{2} / \mathrm{sec}$, measured via the cathodic polarization technique. The replacement of fly ash is effective in facilitating more uniform quality in the column specimens due to a lower level of bleeding water and higher resistance to segregation and pozzolanic reactions.
\end{abstract}

Keywords: Bleeding; Chlorides; Corrosion; Horizontal steel bar; Oxygen permeability

\section{INTRODUCTION}

Conventionally, reinforced concrete (RC) structures have been considered to be maintenancefree because of their highly durable. However, in recent years a decrease in the durability of RC structures caused by the corrosion of steel bars has become a major social problem. These structures are widely used for infrastructure such as tunnels and bridges, but their durability is adversely affected by such corrosion when exposed to aggressive environments, such as chloride and acid attack (Wang et al., 2014). Indonesia is an archipelagic state and many provinces are located in the coastal areas of each island. It is inevitable that corrosion of steel bars embedded in concrete occurs and tends to be caused by chloride ions from the sea environment during the service life. The use of sea sand has also led to the corrosion of steel bars in inland areas.

\footnotetext{
*Corresponding author's email: nevysandra@gmail.com, Tel. +62 821-7182-6663, Fax. +62-751-7055644 Permalink/DOI: https://dx.doi.org/10.14716/ijtech.v10i4.2503
} 
Massive infrastructure development, as one of the realizations of the Nawa Cita (Nine Agendas) throughout the archipelago, such as road and bridge constructions is aimed at making cities in Indonesia more interconnected. The amount of concrete produced has increased in line with the increase in construction work, which could lead to the scarcity of natural resources, such as the sand generally used as fine aggregate. The excavation of sand could have a great effect on the environment. In this regard, an alternative material to replace the main constituent of concrete should be seriously considered. In recent years, the use of industrial by-products such as construction materials has been promoted as a sustainable approach (Shi et al., 2012). For example, the amount of coal ash which produces fly ash (FA) generated from electricity utilities such as coal-fired power plants is about 8.5 million tons in Japan, and around 300,000 tons in Shikoku, according to data published in 2011, and 8.31 million tons in Indonesia in (ESDM, 2019). On the other hand, about 400,000 tons of copper slag is produced annually in Indonesia by the Freeport Company and Newmont Company according to Ministry of Energy and Mineral Resources Republic Indonesia data from 2012, while 2 million tons of copper slag is produced in Japan each year by copper refining in Shikoku (SDAR, 2003).

Much research on the utilization of these materials to produce concrete has been conducted. According to a past study by Nakai et al. (2015), bleeding water tends to increase in fresh concrete mixed with CUS because of its high density of $3.55 \mathrm{~g} / \mathrm{cm}^{3}$. On the other hand, it has been suggested that bleeding water could be reduced by the addition of FA, and long-term strength development is expected from the pozzolanic reaction (Choi et al., 2006). Improving the strength and durability of high strength concrete characteristics has been achieved by the use of copper slag as a sand substitute at levels of up to $40-50 \%$ (by weight of sand) (Al-Jabri et al., 2011). Moreover, the addition of slag to high-performance concrete can increase its strength and produce an anticorrosion effect through enhanced electrical resistivity and reduced permeability (Hou et al., 2004). Copper slag containing $50 \%$ and $65 \%$ of slag replacement when exposed to an aggressive environment has a more refined pore structure than normal concrete, and better resistance to deterioration (Bouikni et al., 2009). Therefore, studies on the durability of concrete, especially on the corrosion of steel bars using copper slag and fly ash with partial replacement, have been the focus of increased attention in recent years. The utilization of copper slag and fly ash in concrete as a solution to the environmental problem of the disposal of industrial waste in large quantities, and the sustainable development associated with the preservation of natural resources, could be a viable solution in Indonesia.

The corrosion resistance of steel bars is a very important materials property in relation to the durability of concrete structures (Hornbostel et al., 2013). Chloride-induced corrosion is known to be most severe form, leading to a higher deterioration rate. Chloride attack is mainly caused by the ingress of chloride ions from the outside into concrete cover in marine environments. The passive film is destroyed and the corrosion of steel bars occurs when the chloride ion concentration at the depth of the bars exceeds the threshold, i.e. $1.2 \mathrm{~kg} / \mathrm{m}^{3}$ (Alonso et al., 2000). The variation in chloride ion concentrations with respect to depth, i.e. their maximum at a certain depth, especially under dry and wet actions was investigated by Andrade and Chang (2018). Various nondestructive tests have been developed and studied to assess corrosion properties, as it is difficult to directly observe the corrosion processes of steel bars embedded in concrete visually. Electrochemical methods such as the half-cell potential method and the polarization resistance method (Bertolini et al., 2016) are promising because the corrosion of steel bars in concrete takes place through electrochemical reactions consuming water and oxygen (Hansson et al., 2006). When corrosion of steel bars occurs, an anodic reaction in which iron ionizes, and a cathodic reaction in which oxygen is reduced, take place on the surface of the reinforcing bar and form a corrosion cell. In the cathodic reaction, oxygen is consumed on the surface of the steel bars; it has been reported that the rate of oxygen permeability is an influencing factor which 
greatly affects the corrosion of steel bars in concrete. In addition, the electrical resistivity of concrete cover is a significant factor contributing to the corrosion processes when macrocell formation occurs (Kawaai \& Ujike, 2016; Otieno et al., 2016).

Pores modified by bleeding water may have a great influence on durability with respect to the ingress of harmful substances and corrosion processes owing to chloride attack or carbonation. Bleeding in a form of segregation is unavoidable in column specimens cast from a cast at height of $1.5 \mathrm{~m}$, thus leading to the formation of the vulnerable zones around the horizontally- placed steel bars. The bleeding affects the integrity of the reinforced concrete owing to the larger gaps or voids formed at the steel and concrete interface. According to past investigation, the bleeding of fresh concrete qualitatively diminishes the durability of horizontal steel bars embedded in concrete structures (Mohammed et al., 2002; Baccay et al., 2004).

Reinforced concrete column specimens were cast using various types of aggregate, including crushed limestone, sandstone and pit sand obtained from regional resources. The presence or absence of CUS and FA replacement was employed as an experimental parameter. The study examined the resistance of horizontally placed steel bars to corrosion resulting from the ingress of chloride ions in column specimens cast with CUS and/or FA replacements, in which the bleeding rate was varied. In particular, a detailed investigation was conducted on the variation in chloride ion concentration in terms of height and depth, corrosion current density, and oxygen permeability on the horizontal steel bars affected by segregation, especially with bleeding water in the column specimens.

\section{METHODS}

\subsection{Specimen Overview}

Reinforced concrete column specimens with a cross-section of $300 \times 300 \mathrm{~mm}$ and height of 1500 $\mathrm{mm}$ were cast from a height of $1.5 \mathrm{~m}$ with a water-to-binder ratio (W/B) of $60 \%$ for OPC mixtures. In the case of FA mixtures, W/B was specified as $52.5 \%$.

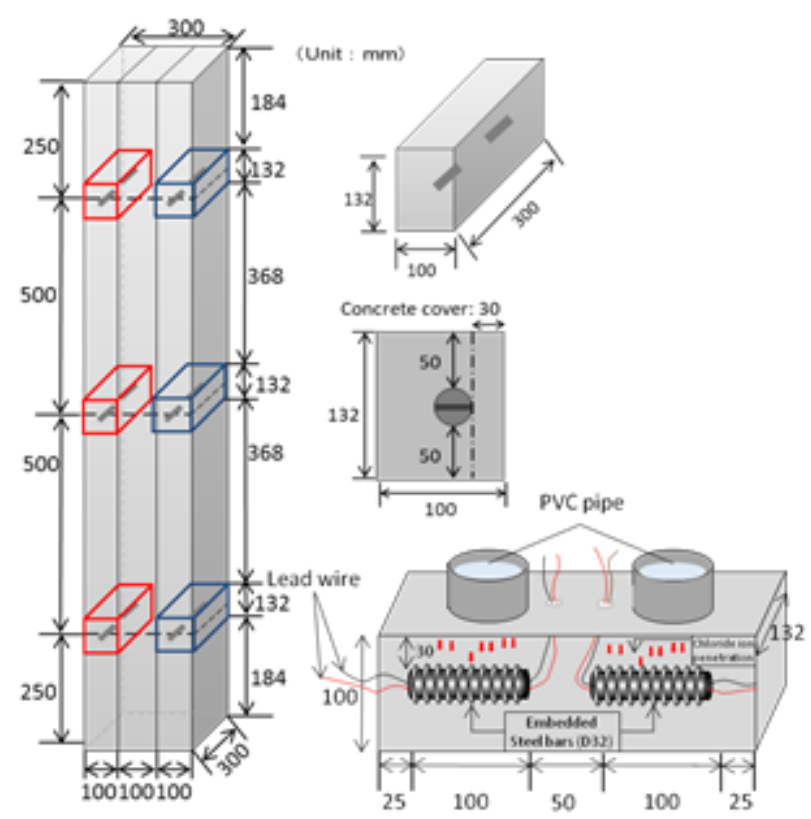

Figure 1a RC column specimen
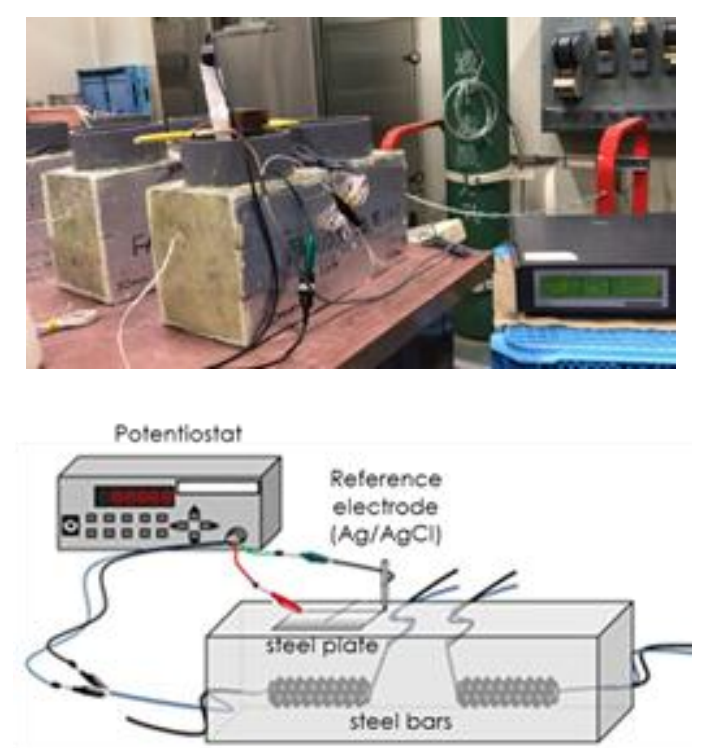

Figure 1b Electro-chemical measurements

Figure 1a shows a schematic of a reinforced concrete column specimen, which was cured in room conditions with temperature controlled at $20^{\circ} \mathrm{C}$ for a period of 28 days. Segmented steel bars comprising D32 deformed steel bars were embedded at heights of 250, 750 and $1250 \mathrm{~mm}$ from 
the bottom surface. Smaller specimens with dimensions of $300 \times 132 \times 100 \mathrm{~mm}$ were cut out from the column specimen with a cover depth of $30 \mathrm{~mm}$ and were used for chloride-induced corrosion tests.

Table 1 shows the mix proportions of the concrete mixtures tested in the experiment. Ordinary Portland Cement (OPC) and fly ash with specific gravities of 3.14 and 2.33 were used as the binding materials, in accordance with JIS Type-ll. Four types of fine aggregate and three types of coarse aggregate were used, as summarized in Table 2. The specified slump and air content for the experiment were $8.0 \mathrm{~cm}$ and $4.0 \%$ respectively. The water reducing agent (WRA) used was a modified lignin sulfonic acid compound, while a modified rosin acid compound type anionic surfactant was used as the air entraining agent (AEA).

Table 1 Mix proportions of concrete specimens

\begin{tabular}{|c|c|c|c|c|c|c|c|c|c|c|c|c|c|}
\hline \multirow{3}{*}{ Mixture } & \multirow{3}{*}{$\begin{array}{l}\mathrm{W} / \mathrm{B} \\
(\%)\end{array}$} & \multicolumn{10}{|c|}{ Unit weight $\left(\mathrm{kg} / \mathrm{m}^{3}\right)$} & \multirow{2}{*}{\multicolumn{2}{|c|}{$\begin{array}{c}\left(\mathrm{g} / \mathrm{m}^{3}\right) \\
\text { Chemical } \\
\text { admixtures }\end{array}$}} \\
\hline & & \multirow{2}{*}{ W } & \multirow[t]{2}{*}{$\mathrm{C}$} & \multirow{2}{*}{ FA } & \multicolumn{4}{|c|}{ Fine aggregate } & \multicolumn{3}{|c|}{$\begin{array}{c}\text { Coarse } \\
\text { aggregate }\end{array}$} & & \\
\hline & & & & & S1 & S2 & S3 & $\mathrm{S} 4$ & G1 & $\mathrm{G} 2$ & G3 & WRA & AEA \\
\hline FACUS 60 & 52.5 & 165 & 251 & 63 & 166 & 169 & - & 731 & 931 & - & - & 1886 & 629 \\
\hline FACUS 30 & 52.5 & 165 & 251 & 63 & - & - & 604 & 366 & - & 469 & 462 & 943 & 2200 \\
\hline CUS60 & 60 & 165 & 275 & - & 179 & 183 & - & 731 & 959 & - & - & 1650 & - \\
\hline OPC & 60 & 165 & 275 & - & 448 & 457 & - & - & 955 & - & - & 4125 & 1375 \\
\hline
\end{tabular}

Table 2 Aggregate properties

\begin{tabular}{ccccc}
\hline $\begin{array}{c}\text { Fine aggregate }(\mathrm{S}) \\
\text { Coarse aggregate }(\mathrm{G})\end{array}$ & Type & $\begin{array}{c}\text { Specific } \\
\text { gravity }\end{array}$ & $\begin{array}{c}\text { Absorption } \\
\text { capacity }\end{array}$ & $\begin{array}{c}\text { Fineness } \\
\text { modulus }\end{array}$ \\
\hline S1 & Crushed sand obtained from sandstone & 2.61 & 1.06 & 2.92 \\
S2 & Crushed sand obtained from limestone & 2.66 & 0.58 & 2.47 \\
S3 & Crushed sand obtained from pit sand & 2.62 & 1.05 & 2.51 \\
S4 & Cooper slag fine aggregate & 3.55 & 0.04 & 2.28 \\
G1 & Crushed sandstone & 2.63 & 1.15 & - \\
G2 & Crushed sandstone & 2.65 & 0.49 & - \\
G3 & Crushed sandstone & 2.61 & 0.66 & - \\
\hline
\end{tabular}

\subsection{Electro-chemical Measurements}

A chloride-induced corrosion test using salt water at a concentration of $10 \%$ was conducted with dry and wet cycles under room conditions, with temperature controlled at $20^{\circ} \mathrm{C}$. The specimens were left in these conditions (dry for 4 days and wet 3 days). Half-cell potential and polarization resistance were measured at the end of each wet period.

\subsubsection{Half-cell potential and corrosion current density}

The potential of the steel bars in concrete was measured by the half-cell potential method. This method examines the possibility of corrosion of steel bars in concrete based on their half-cell potential, depending on the severity of the corrosion in them. It was shown that there was a high possibility that corrosion occurred as the value of the half-cell potential was relatively low. The classification criteria adopted were in accordance with ASTM-C876 (Ji et al., 2016) and are shown in Table 3. 
Table 3 Range of half-cell corrosion potential related to the probability of corrosion

\begin{tabular}{cc}
\hline $\begin{array}{c}\text { Corrosion potential (Ecorr) } \\
(\mathrm{mV} \text { vs. CSE) }\end{array}$ & $\begin{array}{c}\text { Probability of } \\
\text { corrosion }\end{array}$ \\
\hline$<-350 \mathrm{mV}$ & $90 \%$ \\
$(-350 \mathrm{mV})-(-200 \mathrm{mV})$ & Uncertain \\
$>-200 \mathrm{mV}$ & $10 \%$ \\
\hline
\end{tabular}

Table 4 Corrosion current density criteria for reinforcing bars in concrete (CEB)

\begin{tabular}{cc}
\hline $\begin{array}{c}\text { Corrosion Current Density } \\
i_{\text {corr }}\left(\mu \mathrm{A} / \mathrm{cm}^{2}\right)\end{array}$ & Corrosion State \\
\hline$<0.2$ & Passive \\
$0.2-0.5$ & Low corrosion \\
$0.5-1.0$ & Moderate \\
$>1.0$ & High corrosion \\
\hline
\end{tabular}

Half-cell potential and polarization resistance were measured from the same surface on which the water was placed and subsequently removed. Figure $1 \mathrm{~b}$ shows the electro-chemical measurements, consisting of working electrode (embedded steel bars), counter electrode (steel plate), and a reference electrode, which were electrically connected during the measurement. The reference electrode comprised $\mathrm{Ag} / \mathrm{AgCl}$ saturated $\mathrm{KCl}$ and the potentials based on $\mathrm{Cu} / \mathrm{CuSO} 4$ were inferred by the readings. The classification criteria for the corrosion current density according to the European Concrete Committee (CEB) are shown in Table 4.

\subsection{Oxygen permeability}

Cathodic polarization tests were conducted using a potentiostat. The current density was measured when the DC current was impressed based on a rate of $1 \mathrm{mV} / \mathrm{s}$. The current density when the potential difference reached $-860 \mathrm{mV}$ was assumed to reach the limiting current density. The rate of oxygen permeability consumed on the surface of the steel bar embedded in the concrete was calculated based on Equation 1 (Nagataki et al., 1996; Sandra et al., 2019):

$$
\frac{d Q}{d t}=-\frac{i_{\lim }}{n F}
$$

where $d Q / d t$ is the rate of oxygen permeability $\left(\mathrm{mol} / \mathrm{cm}^{2} / \mathrm{sec}\right) ; i_{\text {lim }}$ is the limiting current density $\left(\mathrm{A} / \mathrm{cm}^{2}\right) ; F$ is Faraday's constant $(96,500$ couloms $/ \mathrm{mol})$; and $n$ is the number of electrons exchanged (4).

\subsection{Chloride Ion Concentration}

The chloride ions were measured using a coulometric titration method in accordance with JIS A 1154:2012. The samples were taken by drilling the specimens at depths of $0-15 \mathrm{~mm}, 15-30 \mathrm{~mm}$, $30-45 \mathrm{~mm}, 45-60 \mathrm{~mm}$ and $60-75 \mathrm{~mm}$ from the concrete surface. The chloride ion concentration in each powder sample was calculated based on Equation 2:

$$
C=\frac{W_{1} \times S}{W_{2} \times 100} \times E
$$

where $C$ is the content of chloride ions $\left(\mathrm{kg} / \mathrm{m}^{3}\right) ; W_{1}$ is the weight of the heated distilled water $(\mathrm{g})$; $W_{2}$ is the weight of the sample (g); $S$ is $\mathrm{Cl}^{-}$concentration (\%); and $E$ is the density of the concrete $\left(\mathrm{kg} / \mathrm{m}^{3}\right)$. 


\section{RESULTS AND DISCUSSION}

\subsection{Compressive Strength}

Compressive strength was measured in accordance with JIS A 1108 using cylindrical specimens with a diameter of $100 \mathrm{~mm}$ and height of $200 \mathrm{~mm}$. As can be seen in Figure 2, the strength was comparable among the mixtures tested at the age of 28 days; on the other hand, measured at the age of 91 days it was slightly higher in the FA specimen cases. This was because long-term strength enhancement by the pozzolanic reaction had been obtained.

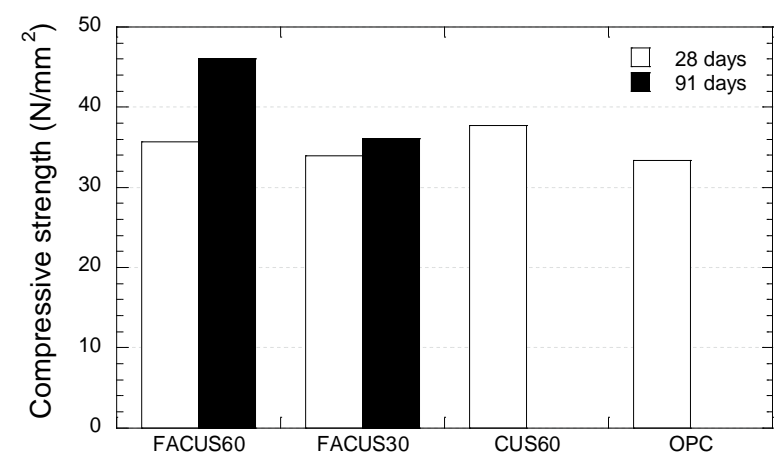

Figure 2 Compressive strength

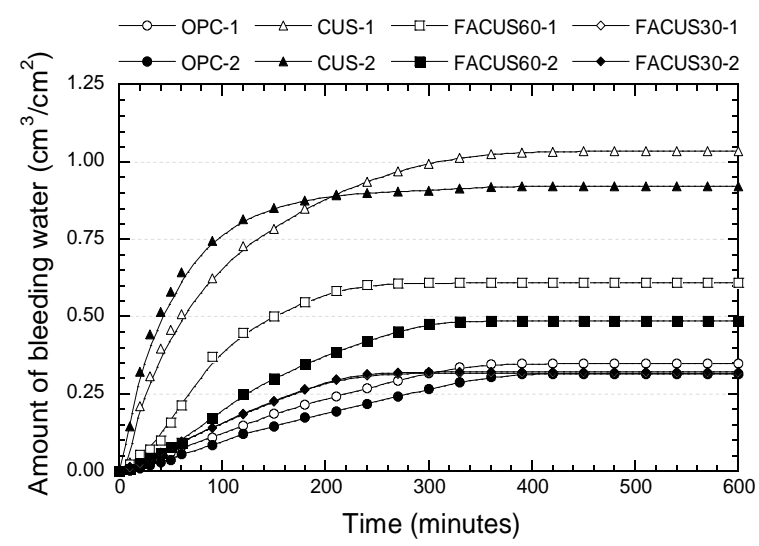

Figure 3 Amount of bleeding water

\subsection{Bleeding Tests}

The bleeding tests in accordance with JIS A 1123-2012 were conducted twice for each specimen. Figure 3 shows the results of the tests; (1) and (2) represent the results of each. From the figure, it can be seen that the amount of bleeding in the case of the CUS60 mixtures is much larger than that measured in the OPC mixture, at $0.33 \mathrm{~cm}^{3} / \mathrm{cm}^{2}$ and $1.0 \mathrm{~cm}^{3} / \mathrm{cm}^{2}$, respectively. The higher density CUS used for the CUS60 mixture resulted in a larger amount of bleeding water as expected. On the other hand, the amount of water in the case of the FA mixtures was $0.55 \mathrm{~cm}^{3} / \mathrm{cm}^{2}$ and $0.32 \mathrm{~cm}^{3} / \mathrm{cm}^{2}$ for FACUS60 and FACUS30, respectively. Compared to the results from the CUS60 mixture, it was confirmed that the amount of bleeding water was reduced in the FACUS60 and FACUS30 mixtures, which is attributed to the FA replacement leading to more resistance against segregation. The results seem to suggest that excessive bleeding water may affect the integrity between the horizontal steel bars and cover concrete when the mixture is cast in the column specimens from a height of $1.5 \mathrm{~m}$.

\subsection{Half-Cell Potential}

Figure 4 shows the half-cell potentials measured in the OPC, the CUS60 and the FA specimens up to 49 cycles. The potentials were varied in the upper, middle and lower parts of the specimens. 
In the case of the OPC specimen, the half-cell potential values after two cycles of dry and wet exposure were observed to be lower than -350 ( $\mathrm{mV}$ vs. CSE). In addition, the half-cell potential values measured in the specimens taken from a height of $1250 \mathrm{~mm}$ decreased significantly after 200 days of monitoring and were lower than -700 ( $\mathrm{mV}$ vs. CSE). In the case of the CUS specimens, as shown in Figure $4 \mathrm{~b}$, corrosion of the steel bars was not observed in the specimens taken from the concrete at a height of $1250 \mathrm{~mm}$. Corrosion of the steel bars was likely to occur in the upper parts $(1250 \mathrm{~mm})$ of FACUS30 and upper parts $(1250 \mathrm{~mm})$ and middle parts $(750$ $\mathrm{mm}$ ) of FACUS60 because the half-cell potential was lower than -350 ( $\mathrm{mV}$ vs. CSE). On the other hand, corrosion was not observed to be severe in the lower part $(250 \mathrm{~mm})$ of either FACUS30 or FACUS60 because the half-cell potentials were close to -200 (mV vs. CSE).
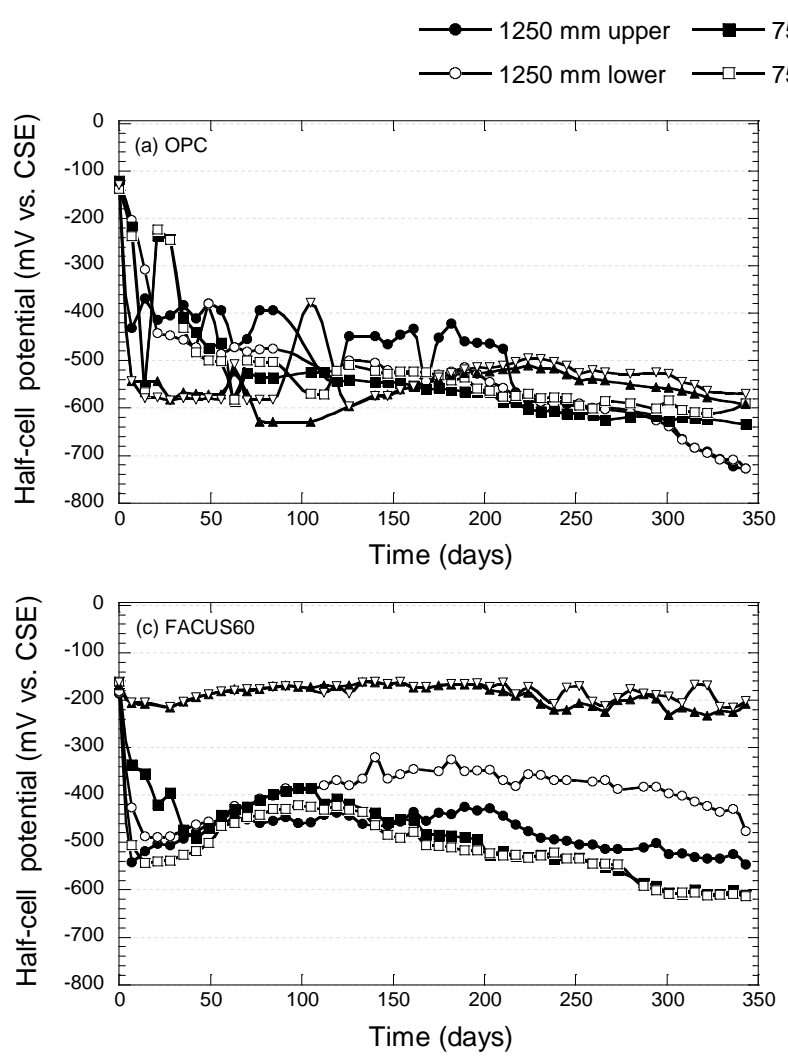

Figure 4 Half-cell potential: (a) OPC;

; (b) CUS60; (c) FACUS60; (d) FACUS30

\subsection{Corrosion Current Density}

The results of the microcell corrosion current density measured by the AC impedance method based on polarization resistance in each specimen are shown in Figure 5. In the cases of the OPC and the CUS60 mixtures, the density was likely to increase from the early stages, thus indicating severe corrosion in the specimen. The results are consistent with those of the half-cell potentials. It should be noted that the corrosion current density measured in the OPC specimens varied in the upper/lower sides of the steel bars. The middle $(750 \mathrm{~mm})$ and the lower $(250 \mathrm{~mm})$ specimens of the CUS60 mixture showed higher corrosion current density. In contrast, lower corrosion current density was observed during the test in the upper specimens. The results are different from the corrosion observed in the OPC specimens. Although the reason for this is not clear, in Section 3.5 it will be examined based on the rate of oxygen permeability and in Section 3.6 on chloride ion concentration.

The corrosion current density decreased for 336 days after the testing of the FA specimens, and was consistently observed both in the FACUS30 and FACUS60 specimens. As shown in Figures $5 \mathrm{c}$ and $5 \mathrm{~d}$, the microcell current density showed relatively higher values up to two cycles, but 
subsequently decreased. The results are consistent with those of half-cell potential, which showed more positive values during the testing periods. From this fact, it assumed that the FA specimens had a smaller amount of bleeding as the higher resistance against material segregation densified the pore structure through the pozzolan reaction around the steel bars and protected them from the ingress of chloride ions. The results seem to suggest that a lower amount of ions and water consumed in the corrosion processes was able to reach the depth of the steel bars, which will be discussed in Sections 3.5 and 3.6.
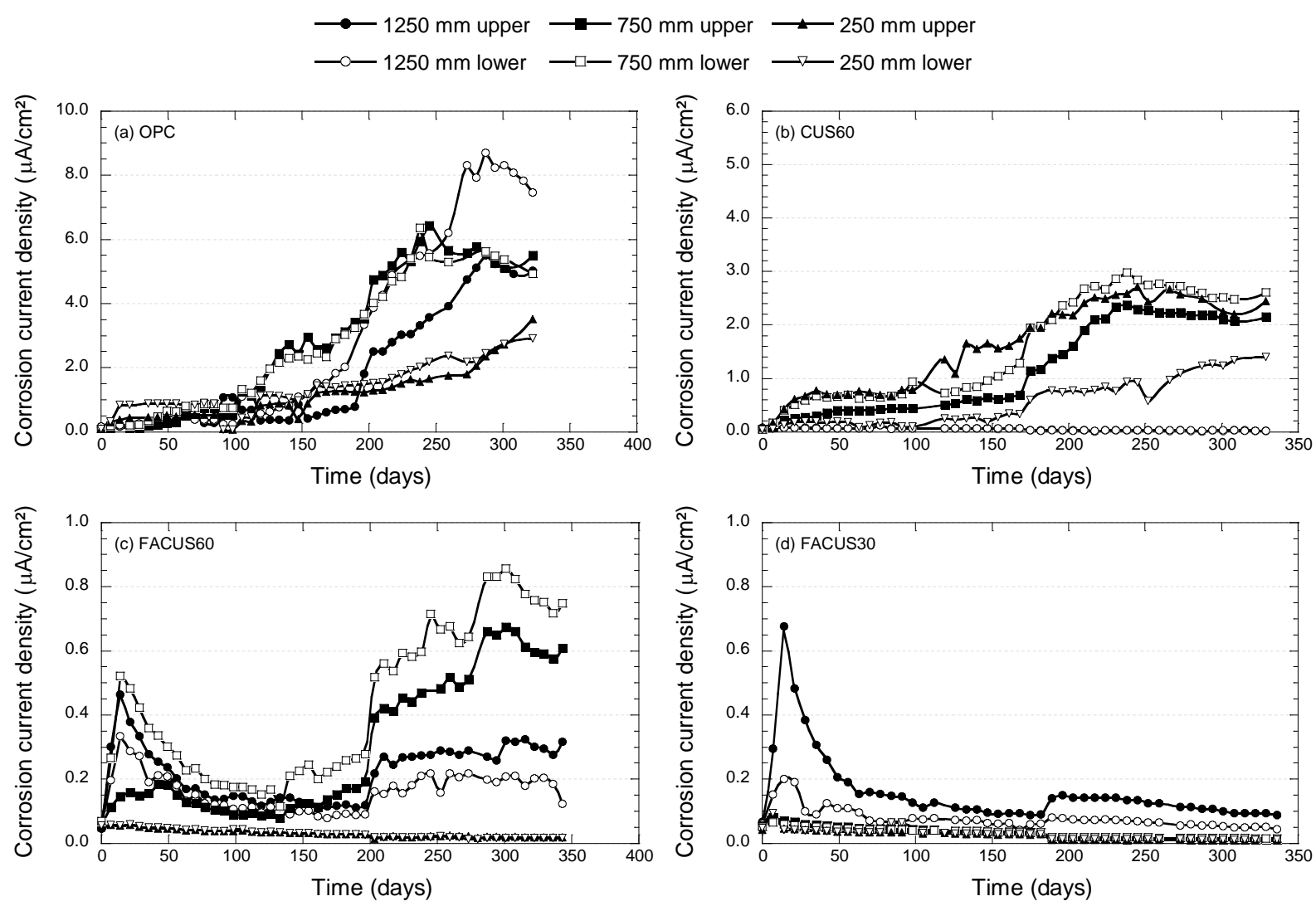

Figure 5 Corrosion current density: (a) OPC; (b) CUS60; (c) FACUS60; (d) FACUS30

\subsection{Oxygen Permeability (Cathodic Polarization)}

The rate of oxygen permeability was measured at the age of 180 days. As can be seen in Figure 6 , among the specimens tested, this rate was lower for the FA mixtures, both in the upper and lower parts of the concrete. In addition, the results indicate that the rate of permeability in the FA mixtures was generally lower on the embedded steel bars. In contrast to these results, the rate of oxygen permeability of OPC and CUS 60 in the lower part of the specimens was $(2.5$ to 5$) \times 10^{-11}$ $\mathrm{mol} / \mathrm{cm}^{2} / \mathrm{sec}$, which is relatively higher than those of the FA mixtures. The specimens taken from a height of $1250 \mathrm{~mm}$ in the CUS60 specimen showed $1.5 \times 10^{-11} \mathrm{~mol} / \mathrm{cm}^{2} / \mathrm{sec}$ or less. These rates were much lower than those observed in the OPC specimens. Therefore, compared to the OPC and the CUS60 mixtures, the rate of oxygen permeability of the FA mixtures was very low (less than $1.0 \times 10^{-11} \mathrm{~mol} / \mathrm{cm}^{2} / \mathrm{sec}$ ). This could be attributed to the fact that the FA mixture reduced the influence of material segregation due to bleeding, which led to a less adverse effect on the integrity of the concrete and steel interface formed in the horizontal steel bar. In addition, pore refinement could have taken place due to pozzolanic reactions in the presence of moisture around the horizontal steel bars. 


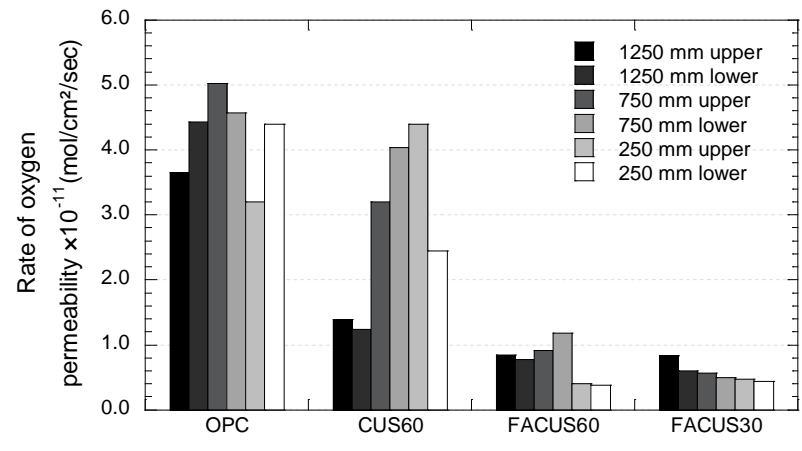

Figure 6 Rate of oxygen permeability

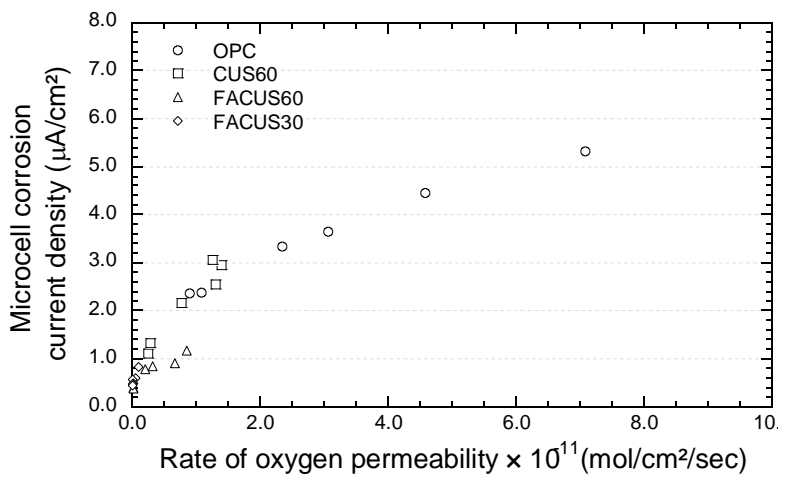

Figure 7 Microcell corrosion current density and rate of oxygen permeability

Figure 7 shows the relationship between the microcell corrosion current density and the rate of oxygen permeability. As can be seen, the corrosion current density increased with a higher rate of oxygen permeability, regardless of the mixture. The rate of oxygen permeability, which indicates the loss of integrity owing to segregation, including bleeding water, affected the microcell corrosion current density. This is more prominent in the case of the OPC and CUS60 mixtures, which is consistent with the results obtained in the bleeding tests. Particularly in the FA mixtures, the results show a lower microcell current density, which could be attributed to the lower rate of oxygen permeability. The formation of initial defects of the concrete around the steel bars is less affected by the bleeding water, thus the penetration of chloride ions is also reduced, which will be discussed in Section 3.6. Moreover, the replacement of FA made it possible to reduce the rate of oxygen permeability by densifying the pore structure and consuming moisture by the pozzolan reaction around the steel bars. Thus, the availability of moisture and dissolved oxygen needed in the cathodic reactions tend to be smaller.

\subsection{Chloride Ion Concentration}

Figure 8 shows the chloride ion content measured up to a depth of $70 \mathrm{~mm}$ from the exposed surface. The results show that the content of chloride ions was generally larger for the OPC cases exceeding the threshold value $1.2 \mathrm{~kg} / \mathrm{m}^{3}$ in all the specimens tested. The chloride ion content was relatively larger in line with higher locations of the OPC specimen tested. In contrast to this result, this content in the CUS60 specimens taken from a height of $1250 \mathrm{~mm}$ showed the lowest amount of chloride ions. This highlights a distinction between the OPC and the CUS60 specimens, in that the resistance against the ingress of chloride ions could be varied with the presence of CUS. Although it was not clear that the presence of CUS could enhance resistance against the diffusion of chloride ions, the effect of CUS replacement on such diffusion will be further investigated in future research. On the other hand, the chloride ion content measured in the FA specimens was generally lower, especially in the deeper zones of the specimens. In addition, this content was slightly higher in the case of the specimens located at a height of $1250 \mathrm{~mm}$; however, the content was comparable among the specimens taken from the three locations in the case of the FACUS30 mixture. Based on the results obtained, it appears that FA replacement is effective in facilitating the formation of more uniform quality in the column specimens, especially in the case of FACUS30. On the other hand, the effect of bleeding on the corrosion process is prominent, even for the OPC specimens. This could be due to the modified resistance against the ingress of corrosive substances including chloride ions, water and dissolved oxygen, especially in the upper parts of the specimens. 

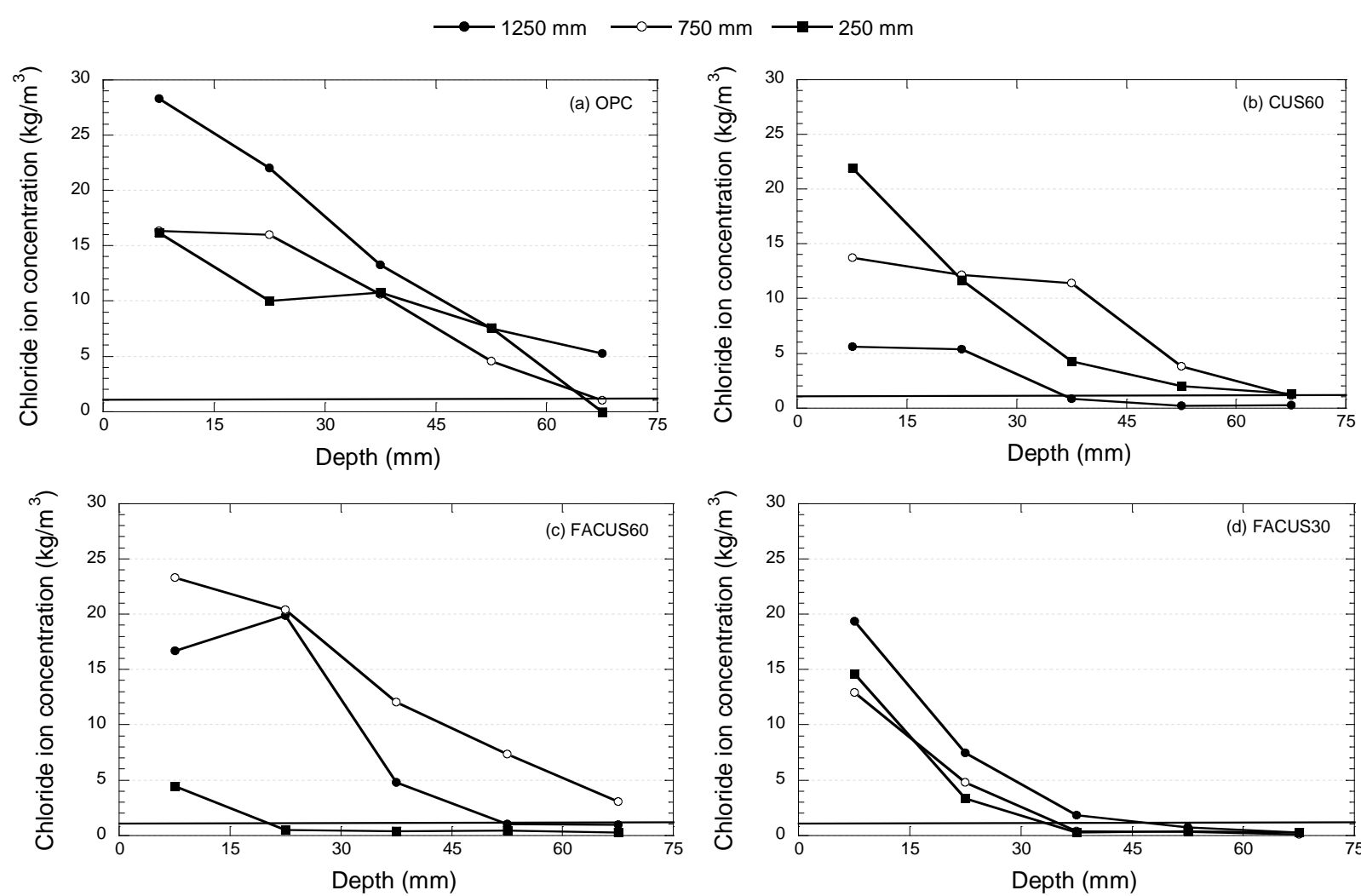

Figure 8 Chloride ion concentration: (a) OPC; (b) CUS60; (c) FACUS60; (d) FACUS30

\section{CONCLUSION}

This study aimed to investigate the effects of bleeding on the corrosion of horizontal steel bars placed in reinforced concrete column specimens cast with CUS and FA. This was examined through electro-chemical tests, including half-cell potential, polarization resistance and corrosion current density, conducted using specimens in which corrosion was induced via dry and wet $(\mathrm{NaCl} \mathrm{10 \% )} \mathrm{cycles.} \mathrm{The} \mathrm{results} \mathrm{suggest} \mathrm{that} \mathrm{the} \mathrm{corrosion} \mathrm{of} \mathrm{the} \mathrm{horizontal} \mathrm{steel} \mathrm{bars} \mathrm{in} \mathrm{the} \mathrm{upper}$ part of the column concrete specimens was adversely affected by bleeding water, even for the OPC specimens with a relatively lower bleeding rate. This was attributed to less resistance against the ingress of corrosive substances including chloride ions, water and dissolved oxygen, especially in the upper part of the column concrete specimens. In the case of the FA mixtures, more uniform pore structure in the column specimens was formed, which led to higher corrosion resistance. This was subsequently improved through pozzolanic reactions, leading to a lower rate of oxygen permeability.

\section{ACKNOWLEDGEMENTS}

This research is fully supported by Department of Civil and Environmental Engineering, Ehime University; Indonesian Endowment Fund for Education (LPDP), Ministry of Finance; and the Directorate General of Higher Education (DIKTI), Ministry of Research, Technology and Higher Education, Republic of Indonesia. This study is financially supported by Grant-in-Aid for Young Scientists (B) 15K18100. 


\section{REFERENCES}

Alonso, C., Andrade, C., Castellote, M., Castro, P., 2000. Chloride Threshold Values to Depassivate Reinforcing Bars Embedded in a Standardized OPC Mortar. Cement and Concrete Research, Volume 30(7), pp. 1047-1055

Al-Jabri, K.S., Al-Saidy, A.H., Taha, R., 2011. Effect of Copper Slag as a Fine Aggregate on the Properties of Cement Mortars and Concrete. Construction and Building Materials, Volume 25(2), pp. 933-938

Andrade, C., Chang, H., 2018. Chloride Profile Induced by Wet-Dry Cycles and Carbonation. In: Service Life Design for Infrastructures, Proceeding of the $4^{\text {th }}$ International Conference, $p$. 214-224

Baccay, M.A., Nishida, T., Otsuki, N., Hamamoto, J., Chin, K., 2004. Influence of Bleeding on Minute Properties and Steel Corrosion in Concrete. Journal of Advanced Concrete Technology, Volume 2(2), pp. 187-199

Bertolini, L., Carsana, M., Gastaldi, M., Lollini, F., Redaelli, E., 2016. Corrosion of Steel in Concrete and Its Prevention in Aggressive Chloride-Bearing Environments. In: Proceeding of $5^{\text {th }}$ International Conference on Durability of Concrete Structures, pp. 13-25

Bouikni, Swamy R.N., Bali A., 2009. Durability Properties of Concrete Containing 50\% and 65\% Slag. Construction and Building Materials, Volume 23(8), pp. 2836-2845

Choi, Y.S., Kim, J.G., Lee, K.M., 2006. Corrosion Behavior of Steel Bar Embedded in Fly Ash Concrete. Corrosion Science, Volume 48(7), pp. 1733-1745

Hansson, C.M., Poursaee, A., Laurent, A., 2006. Macrocell and Microcell Corrosion of Steel in Ordinary Portland Cement and High-Performance Concretes. Cement and Concrete Research, Volume 36(11), pp. 2098-2102

Hornbostel, K. Larsen, C.K., Geiker, M.R., 2013. Relationship between Concrete Resistivity and Corrosion Rate. Cement and Concrete Composites, Volume 39, pp. 60-72

Hou, W., Chang, P., Hwang, C., 2004. A Study on Anticorrosion Effect in High-Performance Concrete by the Pozzolanic Reaction of Slag. Cement and Concrete Research, Volume 34(4), pp. 615-622

ESDM, Ministry of Energy and Mineral Resources Republic of Indonesia., 2019. Data Center and Energy Information of ESDM Department

Ji, Y., Hu, Y., Zhang, L., Bao, Z., 2016. Laboratory Studies on Influence of Transverse Cracking on Chloride-Induced Corrosion Rate in Concrete. Cement and Concrete Composites, Volume 69, pp. 28-37

Kawaai, K., Ujike, I., 2016. Influence of Bleeding on Durability of Horizontal Steel Bars in RC Column Specimen. In: Life-Cycle of Engineering Systems: Emphasis on Sustainable Civil Infrastructure, Proceedings of the Fifth International Symposium, pp. 839-846

Mohammed, T.U., Otsuki, N., Hamada, H., Yamaji, T., 2002. Chloride-Induced Corrosion of Steel Bars in Concrete with Presence of Gap at Steel-Concrete Interface. ACI Materials Journal, Volume 99(2), pp. 149-156

Nagataki, S., Otsuki, N., Moriwake, A., Miyazato, S., 1996. The Experimental Study on Corrosion Mechanism of Reinforced Concrete at Local Repair Part. Journal of Materials, Concrete Structures and Pavements, Volume 32, pp. 109-119 (in Japanese)

Nakai, I., Takamoto, N., Kawaai, K., Ujike, I., 2015. Development of Concrete Mixture Mixed with Copper Slag Fine Aggregate and Fly Ash for Reducing Drying Shrinkage. In: Proceedings of Japan Concete Institute, Volume 37(1), pp. 463-468

Otieno, M., Beushausen, H., Alexande. M., 2016. Chloride-induced Corrosion of Steel in Cracked Concrete - Part I: Experimental Studies under Accelerated and Natural Marine Environments. Cement and Concrete Research, Volume 79, pp. 373-385 
Sandra, N., Kawaai, K., Ujike, I., 2019. Corrosion Current Density of Macrocell of Horizontal Steel Bars in Reinforced Concrete Column Specimen. International Journal of Geomate, Volume 16(54), pp. 123-128

SDAR, Shikoku District Aggregate Resource Measure Study Committee, 2003. Basic Policies on Shikoku District Aggregate Resource

Shi, X., Xie, N., Fortune, K., Gong, J., 2012. Durability of Steel Reinforced Concrete in Chloride Environments. Construction and Building Materials, Volume 30, pp. 125-138

Wang, Z., Zeng, Q., Wang, L., Yao, Y., Kefei L., 2014. Corrosion of Rebar in Concrete under Cyclic Freeze-Thaw and Chloride Salt Action. Construction and Building Materials, Volume 53, pp. 40-47 